\title{
Research on Competency Evaluation of Accounting Applied Talents
}

\author{
Zhihong Zhu* \\ Institute of Petroleum Economics and Management \\ Northeast Petroleum University \\ Daqing, China \\ Yanmei Sheng \\ Institute of Petroleum Economics and Management \\ Northeast Petroleum University \\ Daqing, China
}

\author{
Jie Gao \\ Institute of Petroleum Economics and Management \\ Northeast Petroleum University \\ Daqing, China \\ Yucui Wang \\ Institute of Petroleum Economics and Management \\ Northeast Petroleum University \\ Daqing, China
}

\begin{abstract}
In order to evaluate the competency of accounting applied talents, this paper constructs a competency evaluation model for accounting applied talents based on factor analysis. Firstly, the evaluation index system of accounting applied talents competency is constructed from the four dimensions of learning ability, professional judgment ability, comprehensive management ability and self-discipline ability. Secondly, the data is collected through questionnaires, and the data is descriptively analyzed, validity analyzed and reliability analyzed to determine the validity of the survey data. Finally, based on the results of statistical analysis, the competency evaluation model of accounting applied talents based on factor analysis method is constructed for the different needs of junior, intermediate and senior accounting talents. The research results show that the ability of Chinese accountants is at a good level, but the scores of legal and regulatory professional knowledge ability, operational ability and comprehensive business ability are relatively low. The competency evaluation model of accounting applied talents based on factor analysis method is applicable to the evaluation of competency of different levels of Chinese accounting talents, and it may provide direction for improving the competency of Chinese accounting applied talents.
\end{abstract}

Keywords—accounting applied talents; competency; evaluation

\section{INTRODUCTION}

With the continuous development of society and economy, the functions of accountants are also constantly changing. Competency has gradually become a comprehensive indicator to measure whether accountants are competent for actual jobs.[1] Therefore, it is of great significance to scientifically measure the competency of the application-oriented in accounting for enterprises to recruit talents, colleges to cultivate talents, and accountants to improve their comprehensive quality. Requirements on the competence vary due to the different nature of their work. Basic position requires higher learning ability of financial accounting and regulations.

This work was supported by Heilongjiang Philosophy and Social Science Research Project of China (No.18JYB143), Heilongjiang Higher Education Teaching Reform Project of China (No. SJGY20180074), Heilongjiang Education Science "13th Five-Year Plan" Key Project of China (No. GBB1318019), Graduate Education Teaching Reform Research Project of Northeast Petroleum University of China (No. JYCX JG08_2018).
Professional judgment ability in financing, restructuring and other important business is indispensable for intermediate managers, such as the chief financial officer and even the CFO [2]. The comprehensive capability is the most important index to measure the senior managers. This thesis intended to analyze the emphasis of different positions on the ability of accountants, construct the competency model of accounting applicated talents, evaluate the competency scientifically, and provide a reference for accounting professionals to improve their competitiveness.

\section{COMPETENCY EVALUATION INDEX SYSTEM OF ACCOUNTING APPLIED TALENTS}

By reading literature and conducting research on finance personnel and executives, some indicators affecting the competency were preliminarily confirmed, and then build an evaluation index system for the competency of accounting applicated talents, as shown in TABLE I. 
TABLE I.

COMPETENCY EVALUATION INDEX SYSTEM OF ACCOUNTING APPLIED TALENTS

\begin{tabular}{|c|c|c|}
\hline Primary evaluation index & Secondary evaluation index & Three-level evaluation index \\
\hline \multirow{7}{*}{$\begin{array}{l}\text { Study } \\
\text { (S) }\end{array}$} & Operational capability $\left(\mathrm{S}_{1}\right)$ & Financial software $\left(\mathrm{S}_{11}\right)$ \\
\hline & \multirow{3}{*}{ Professional $\left(\mathrm{S}_{2}\right)$} & Financial accounting $\left(\mathrm{S}_{21}\right)$ \\
\hline & & Management accounting $\left(\mathrm{S}_{22}\right)$ \\
\hline & & Audit $\left(\mathrm{S}_{23}\right)$ \\
\hline & \multirow{3}{*}{ Laws and regulations $\left(\mathrm{S}_{3}\right)$} & Accounting principle $\left(\mathrm{S}_{31}\right)$ \\
\hline & & Tax law $\left(\mathrm{S}_{32}\right)$ \\
\hline & & Economic law $\left(\mathrm{S}_{33}\right)$ \\
\hline \multirow{2}{*}{ Judgment (J) } & Basic Judgment $\left(\mathrm{J}_{1}\right)$ & Authenticity $\left(\mathrm{J}_{11}\right)$ \\
\hline & Professional judgment $\left(\mathrm{J}_{2}\right)$ & Business transaction $\left(\mathrm{J}_{21}\right)$ \\
\hline \multirow{5}{*}{ Management (M) } & \multirow{2}{*}{$\begin{array}{c}\text { Interpersonal skill } \\
\left(\mathrm{M}_{1}\right)\end{array}$} & Communication and coordination $\left(\mathrm{M}_{11}\right)$ \\
\hline & & Organization and management $\left(\mathrm{M}_{12}\right)$ \\
\hline & \multirow{3}{*}{ Comprehensive capability $\left(\mathrm{M}_{2}\right)$} & Strategy $\left(\mathrm{M}_{21}\right)$ \\
\hline & & Forward-looking perspective $\left(\mathrm{M}_{22}\right)$ \\
\hline & & Outsight $\left(\mathrm{M}_{23}\right)$ \\
\hline \multirow{4}{*}{ Self-Discipline (D) } & \multirow{2}{*}{$\begin{array}{l}\text { Professional ethics } \\
\qquad\left(D_{1}\right)\end{array}$} & Cherish and devote to work $\left(\mathrm{D}_{11}\right)$ \\
\hline & & Honesty and trustworthiness $\left(D_{12}\right)$ \\
\hline & \multirow{2}{*}{ The values $\left(\mathrm{D}_{2}\right)$} & Law-abiding $\left(\mathrm{D}_{21}\right)$ \\
\hline & & Objective and fair $\left(\mathrm{D}_{22}\right)$ \\
\hline
\end{tabular}

As can be seen from TABLE I, the competency evaluation index system of application-oriented accounting talents included four first-level evaluation indexes--learning, professional judgment, comprehensive management and selfdiscipline ability. Learning ability mainly included the basic financial accounting knowledge, the basic operational capabilities of financial software, the adaptability to constantly updated accounting standards and understanding of various laws and regulations [3]. Professional judgment ability mainly referred to the sensitivity to the authenticity of all kinds of business information and economic operations. The comprehensive management capabilities mainly included interpersonal skills based on communication and organizational management, and the comprehensive business ability of strategic thinking and forward-looking observation [4]. Selfdiscipline ability included basic professional ethics of honesty and trustworthiness, obedience to the law and the values of objective and fair.

\section{CONSTRUCTION OF ACCOUNTING APPLIED TALENTS COMPETENCY MODEL}

\section{A. Data Sources}

The basic data information was collected by questionnaire. SPSS software was used to sort out and analyze the data collected in the questionnaire [5-6]. And then constructed the competency model for application-oriented in the primary, intermediate and advanced accounting talents.

\section{1) Design the questionnaire}

There were three parts in the questionnaire:

a) Basic information of respondents. This part covered four questions, including the working place, the working years, the position department, the position nature and industry, etc., this part was the basis of the whole questionnaire. b) The four major competencies of accounting talents. This part mainly analyzed the importance of learning, professional judgment, comprehensive management and self-discipline ability.

c) Specific evaluation indexes of accounting competence. This part was divided into four sections. Each section analyzed the importance of the secondary and tertiary indicators under the four dimensions of learning, professional judgment, comprehensive management and self-discipline ability.

The second and third parts of the questionnaire were the key to the entire study [7]. At the same time, respondents can supplement and improve the incomplete and imperfect parts of the questionnaire.

\section{2) Determine the respondent}

To ensure the validity, the main research object of this survey was the alumni of northeast petroleum university who are engaged in accounting work [8-9]. In addition, relying on the existing social network of school teachers, questionnaires were distributed to middle and senior managers of some enterprises.

\section{3) Collect the data}

According to the content of the questionnaire, the respondents were divided into three groups based on their work positions: primary, intermediate and advanced. The research objects were located in Beijing, Shanghai, Guangdong, Zhejiang, Shandong, Sichuan, Chongqing, Hunan, Xinjiang, Liaoning and Heilongjiang province, which can effectively avoid the impact of regional differences on the questionnaire results. The industries included petrochemical, real estate, manufacturing, service, transportation, catering and clothing, etc., covering most industries, which can eliminate the influence of different industry backgrounds [10]. 


\section{B. Statistics and analysis of results}

572 questionnaires were collected in this survey, and 41 unqualified questionnaires were removed. A total of 531 valid questionnaires were obtained. Among them, 258 were junior positions, 180 were intermediate positions and 93 were senior positions. The results of the questionnaire were analyzed by SPSS 19.0 as follows:

\section{1) Descriptive statistical analysis}

TABLE II. WORKING YEARS STATISTICS

\begin{tabular}{|c|c|c|}
\hline Working hours & Frequency & Rate \\
\hline Less than 3 years & 193 & $36.35 \%$ \\
\hline 4-7 years & 163 & $30.70 \%$ \\
\hline 8-10 years & 116 & $21.85 \%$ \\
\hline More than 10 years & 59 & $11.1 \%$ \\
\hline Total & 531 & $100 \%$ \\
\hline
\end{tabular}

TABLE III. POSITIONS STATISTICS

\begin{tabular}{|c|c|c|}
\hline Working hours & Frequency & Rate \\
\hline Accountant and cashier & 207 & $38.98 \%$ \\
\hline Finance director & 104 & $19.59 \%$ \\
\hline Finance manager & 122 & $22.98 \%$ \\
\hline Chief Financial Officer & 61 & $11.49 \%$ \\
\hline General manager & 37 & $6.96 \%$ \\
\hline Total & 531 & $100 \%$ \\
\hline
\end{tabular}

It can be concluded from TABLE II and TABLE III that the majority of the respondents who were engaged in primary jobs was the largest, and the higher the position was, the smaller the number of respondents would be. And the proportion was similar to the working years, which was in line with the normal law. The results ensured the credibility of the results of the questionnaire initially.

2) Reliability analysis

TABLE IV. RELIABILITY ANALYSIS

\begin{tabular}{|c|c|c|}
\hline Category & Cronbach $\boldsymbol{\alpha}$ & Number \\
\hline Study & 0.731 & 7 \\
\hline Judgment & 0.692 & 2 \\
\hline Management & 0.679 & 5 \\
\hline Self-Discipline & 0.704 & 4 \\
\hline Overall questionnaire & 0.653 & 18 \\
\hline
\end{tabular}

As can be seen from TABLE IV, the Cronbach values of the four dimensions and the overall questionnaire were all greater than 0.6, indicating that the questionnaire data was credible and can be analyzed in the next step.

\section{3) Validity analysis}

As can be seen from TABLE V, the load on all four factors was greater than 0.65 , indicating that the structural validity of the questionnaire was good and can meet the empirical research standard.
TABLE V. VALIDITY ANALYSIS

\begin{tabular}{|c|c|c|c|c|}
\hline \multirow{2}{*}{} & \multicolumn{4}{|c|}{ Component } \\
\hline & $\boldsymbol{S}_{\boldsymbol{1}}$ & $\boldsymbol{J}_{\mathbf{2}}$ & $\boldsymbol{M}_{\mathbf{3}}$ & $\boldsymbol{D}_{\boldsymbol{4}}$ \\
\hline $\mathrm{S}_{11}$ & 0.904 & & & \\
\hline $\mathrm{S}_{21}$ & 0.846 & & & \\
\hline $\mathrm{S}_{22}$ & 0.815 & & & \\
\hline $\mathrm{S}_{23}$ & 0.768 & & & \\
\hline $\mathrm{S}_{31}$ & 0.722 & & & \\
\hline $\mathrm{S}_{32}$ & 0.709 & & & \\
\hline $\mathrm{S}_{33}$ & 0.673 & & & \\
\hline $\mathrm{J}_{11}$ & & 0.831 & & \\
\hline $\mathrm{J}_{21}$ & & 0.784 & & \\
\hline $\mathrm{M}_{11}$ & & & 0.942 & \\
\hline $\mathrm{M}_{12}$ & & & 0.900 & \\
\hline $\mathrm{M}_{21}$ & & & 0.860 & \\
\hline $\mathrm{M}_{22}$ & & & 0.793 & \\
\hline $\mathrm{M}_{23}$ & & & 0.737 & \\
\hline $\mathrm{D}_{11}$ & & & & 0.891 \\
\hline $\mathrm{D}_{12}$ & & & & 0.838 \\
\hline $\mathrm{D}_{21}$ & & & & 0.785 \\
\hline $\mathrm{D}_{22}$ & & & & 0.726 \\
\hline
\end{tabular}

C. Construction of accounting applicated talents competency model based on factor analysis

Suitability tests were performed on factor analysis. The test results are shown in TABLE VI. After Kaiser normalized orthogonal rotation, the explained total variance and component score matrix are shown in TABLE VII.

TABLE VI. KMO AND BARTLET’S TEST

\begin{tabular}{|c|c|c|}
\hline KMO Measure of Competency & & 0.630 \\
\hline \multirow{3}{*}{ Bartlett's Test of Competency } & Approx. Chi-Square & 17782.860 \\
\cline { 2 - 3 } & Df & 136 \\
\cline { 2 - 3 } & Sig. & 0.000 \\
\hline
\end{tabular}

TABLE VII. TOTAL VARIANCE EXPLAINED

\begin{tabular}{|c|c|c|c|c|c|c|}
\hline \multirow{2}{*}{ Component } & \multicolumn{3}{|c|}{ Initial Eigenvalue } & \multicolumn{3}{|c|}{$\begin{array}{c}\text { Rotation Sums of Squared } \\
\text { loadings }\end{array}$} \\
\hline & Total & $\begin{array}{c}\% \text { of } \\
\text { variance }\end{array}$ & $\begin{array}{c}\text { Cumulative } \\
\%\end{array}$ & Total & \begin{tabular}{|c|}
$\%$ of \\
variance
\end{tabular} & $\begin{array}{c}\text { Cumulative } \\
\%\end{array}$ \\
\hline 1 & 4.230 & 29.382 & 29.382 & 3.083 & 28.374 & 28.374 \\
\hline 2 & 3.483 & 23.407 & 52.789 & 2.693 & 23.869 & 52.243 \\
\hline 3 & 2.363 & 16.902 & 69.691 & 2.349 & 16.839 & 69.082 \\
\hline 4 & 1.472 & 12.204 & 81.895 & 2.238 & 12.813 & 81.895 \\
\hline 5 & 0.873 & 5.431 & 87.326 & & & \\
\hline 6 & 0.241 & 3.098 & 90.424 & & & \\
\hline 7 & 0.634 & 2.431 & 92.855 & & & \\
\hline 8 & 0.615 & 2.010 & 94.865 & & & \\
\hline 9 & 0.446 & 1.396 & 94.486 & & & \\
\hline 10 & 0.342 & 1.214 & 95.882 & & & \\
\hline 11 & 0.301 & 0.872 & 97.096 & & & \\
\hline 12 & 0.147 & 0.815 & 97.968 & & & \\
\hline 13 & 0.129 & 0.557 & 98.783 & & & \\
\hline 14 & 0.064 & 0.289 & 99.340 & & & \\
\hline 15 & 0.048 & 0.203 & 99.629 & & & \\
\hline 16 & 0.025 & 0.096 & 99.832 & & & \\
\hline 17 & 0.011 & 0.062 & 99.990 & & & \\
\hline 18 & 0.002 & 0.010 & 100.000 & & & \\
\hline
\end{tabular}

It can be seen from TABLE VI that the KMO was 0.630 , and the approximate chi-square of the Bartlett sphericity test was 17782.860 , corresponding to a p-value of 0.000 , which passed the significance test and was shown to be suitable for factor analysis. In the factor analysis of application-oriented 
accounting talents competency, the four factors with eigenvalues greater than 1 were extracted and their accumulative variance contribution was $81.895 \%$. From TABLE V, the common-factor variance of all the indicators was almost greater than 0.7 , indicating that the common factor well reflected the original indicators information. The common factor reflects the information of the original indicator very well. Taking the proportion of the variance contribution of 4 common factors as the weight, the comprehensive score function of the application-oriented accounting talents competency after weighted aggregation is:

$$
P=(28.374 S+23.869 J+16.839 M+12.813 D) / 81.895
$$

For the secondary and tertiary evaluation indexes, the weight in the competency evaluation model was determined by the scores in the questionnaire statistical results.

\section{Evaluation of Accounting Applied TAlents COMPETENCY}

After the establishment of the above model, the competency of the investigated object as the research sample was calculated, as shown in TABLE VIII. It is set that the evaluation score of this samples is above 9 points as excellent, 8-9 as good, 7-8 as medium, 6-7 as qualified and below 6 as unqualified. It can be seen from TABLE VIII that the ability varies among different positions. For junior accountants, the abilities were all excellent or good except comprehensive business capabilities. Intermediate and senior accountants were in good or above in each ability, and for senior accountant, the values, comprehensive business and judgment ability have reached excellent. In terms of competency, the comprehensive competency of senior accounting talents was the highest, with a score of 9.03, reaching the excellent level. The competency of junior and intermediate accounting talents was at a good level, with a score of 8.71 and 8.89 respectively. The overall competency score of accounting talents surveyed was 8.84 points, which was at a good level.

It can be concluded from TABLE VIII that the higher the job position is, the stronger the competence of accountant is, indicating that accountant needs to continuously improve their competence to adapt to the responsibilities of senior jobs. The result also showed that the competence of accountants was continuously improved with work experience. On the whole, the competency of all abilities was all above good level, but the scores of the professional knowledge of laws and regulations, operational ability and comprehensive business ability are relatively low, which was the weakness of all accountants at present.

TABLE VIII. COMPETENCY EVALUATION RESULT

\begin{tabular}{|c|c|c|c|c|}
\hline & Primary & Intermediate & Senior & Overall \\
\hline $\begin{array}{c}\text { Operational } \\
\text { capability }\end{array}$ & 8.94 & 8.47 & 8.23 & 8.61 \\
\hline Professional & 8.21 & 8.74 & 8.97 & 8.58 \\
\hline Laws and regulations & 8.04 & 8.39 & 8.96 & 8.36 \\
\hline Basic Judgment & 8.92 & 9.15 & 9.07 & 9.05 \\
\hline $\begin{array}{c}\text { Professional } \\
\text { judgment }\end{array}$ & 8.53 & 8.79 & 9.14 & 8.75 \\
\hline
\end{tabular}

\begin{tabular}{|c|c|c|c|c|}
\hline \multicolumn{5}{|c|}{ Cont. to TABLE VIII } \\
\hline Interpersonal skill & 8.93 & 8.83 & 9.01 & 8.90 \\
\hline $\begin{array}{c}\text { Comprehensive } \\
\text { capability }\end{array}$ & 7.83 & 8.45 & 9.03 & 8.32 \\
\hline Professional ethics & 9.13 & 8.98 & 8.74 & 8.99 \\
\hline The values & 9.31 & 9.28 & 9.35 & 9.30 \\
\hline Competency & 8.71 & 8.89 & 9.03 & 8.81 \\
\hline
\end{tabular}

\section{CONCLUSION}

(1) The competency of accounting applied talents is a comprehensive ability system including learning, professional judgment, comprehensive management, and self-discipline ability. However, the accountants on different positions require different emphasis on their ability to work.

(2) The competency evaluation model for accounting applied talents constructed in this paper quantifies the four abilities. It can evaluate their competency more intuitively and provide more convenient evaluation methods for enterprises to recruit talents. It can point out a clearer training plan for talents in colleges and provide a clearer direction for individuals to improve their self-abilities.

(3) Based on the results of the evaluation results, the following measures were proposed to improve the competency of accounting applied talents: 1) Strengthen the study of professional knowledge and relevant laws; 2) Strengthen the cultivation of professional ability; 3) Adhere to the edification of professional ethics; 4) Formulate incentive system.

\section{REFERENCES}

[1] Zhang Qin. Research on the Competency Evaluation of Accounting Talents in the Information Environment[D].Shanxi University of Finance and Economics, 2015. (In Chinese)

[2] Xu Fei. Preliminary construction of accounting personnel competency model[D].Central China Normal University, 2015. (In Chinese)

[3] Hu Lixin, Yan Hao. Analysis of China's CFO Demand Information and Suggestions for Accounting Professionals-Based on the Analysis of IMA Management Accounting Competency Framework [J].Commercial Accounting, 2018(03):107-109. (In Chinese)

[4] Hua Youzhen, Zou Anquan, Yang Wangcheng, Xin Huanping, Yin Na. Design of Recruitment Scheme for Enterprise Accountants Based on Competency Model[J]. Enterprise Technology Development, 2017, 36(04):18-20. (In Chinese)

[5] Yang Yuhe. Analysis of the Competency of Accounting Talents in the Information Environment[J]. Modern Economic Information, 2018(09): 54+56. (In Chinese)

[6] Zhang Shufeng, Zhu Yongyue, Yang Weixing, Ouyang Chenhui. Construction and Evaluation of Skilled Personnel Competency Model in the Background of Manufacturing Service [J].Science and Technology Progress and Policy, 2018, 35(08):119-127. (In Chinese)

[7] Wang Jian, Ping Siyu, Sun Hongliang. Strategies for Improving the Competency of Accounting Personnel Driven by "Internet +"[J]. Finance and Accounting Monthly, 2016(23):19-23. (In Chinese)

[8] Dong Shulan, Yang Yanhua. Research on the Evaluation of Professional Competency of Senior Accountants in Enterprises-Research Data from Heilongjiang Province[J].Friends of Accounting, 2013(17):111-116. (In Chinese)

[9] Song Chunling. Analysis on the Construction of the Capability Framework of Enterprise Accounting Leaders in China[J].Finance \& Accounting, 2013(12):46-47. (In Chinese)

[10] Jingwen, Wu Zhunan, Yin Ruichao. A Research on Accounting Professional Competency Evaluation Based on Rough-Unascertained Measure[J].Friends of Accounting, 2018 (04) :138-141. (In Chinese) 